\title{
The Isolation and Characterization of Mutant Strains of the Blue-green Alga Anacystis nidulans
}

\author{
By M. HERDMAN AND N. G. CARR \\ Department of Genetics and Department of Biochemistry, \\ The University, P.O. Box I47, Liverpool, L69 3BX
}

(Accepted for publication I3 October 1971)

\begin{abstract}
SUMMARY
Procedures for mutagenesis and conditions for selection by penicillin enrichment in the blue-green alga Anacystis nidulans have been developed. The characterization of I9 mutant strains involving single or serially induced multiple markers was achieved. In addition to drug-resistant and morphological mutants auxotrophic strains requiring phenylalanine, methionine, biotin or acetate together with strains deficient in sulphate and nitrate reduction have been isolated.
\end{abstract}

\section{INTRODUCTION}

Previous attempts to isolate mutants of blue-green algae have had only limited success, and in particular auxotrophic mutants have proved difficult to obtain. Although several species of blue-green algae are significantly more resistant to $\gamma$-radiation than are bacteria (Kraus, I966) other mutagens, ultraviolet light (u.v.) and $N$-methyl- $N^{\prime}$-nitro- $N$-nitrosoguanidine (NTG) are comparably lethal to species from both groups of procaryotic organisms. Mutations affecting u.v. and drug resistance have proved the most readily recovered, and several such mutants of the unicellular blue-green alga Anacystis nidulans have been reported although not always as clonally pure strains (Kumar, 1962, 1963, 1965; Singh, Singh \& Sinha, 1966; Pikalek, 1967; Bazin, 1968; Asato \& Folsome, 1969; Shestakov \& Khyen, 1970). Morphological and pigment alterations have been shown in mutants of Anabaena cycadeae (Singh \& Singh, I964a), Anabaena doliolum (Singh \& Singh, I964b), Nostoc linchia (Singh \& Tiwari, I969), Plectonema boryanum (Padan \& Shilo, 1969), Agmenellum quadruplicatum (Ingram \& Van Baalen, 1970) as well as in the more studied Anacystis nidulans (Van Baalen, 1965; Kunisawa \& Cohen-Bazire, 1970). The best characterized auxotrophic mutants of blue-green algae are the nitrate-reductase and nitrite-reductase mutants of Agmenellum quadruplicatum described by Stevens \& Van Baalen (1970); strains of Anacystis nidulans lacking nitrate reductase have also been isolated (Van Baalen, 1965). The requirement for a non-specific reduced carbon source has been reported in a mutant of Phormidium mucicola (Srivastava, 1969) and in Anacystis doliolum (Singh \& Singh, 1964b). This communication describes the development of conditions for mutation and penicillin enrichment which have led to the isolation of I 9 mutant strains of Anacystis nidulans which carry single or multiple mutations affecting morphological, drug resistance and nutritional characters.

\section{METHODS}

Organism. The parent strain for all the mutants isolated was Anacystis nidulans, no. 625 of the Culture Collection of Algae at Indiana University, Department of Botany, Bloomington, Indiana, U.S.A. 
Culture media and conditions. Anacystis nidulans was grown in liquid culture and on agar plates as previously described (Herdman, Faulkner \& Carr, 1970).

Supplemented media. For the isolation and growth of mutants Allen's media was supplemented with the necessary growth factors at the concentrations listed below: inorganic salts, $\mathrm{NH}_{4} \mathrm{Cl}, 3 \mathrm{~mm} ; \mathrm{Na}_{2} \mathrm{~S}_{2} \mathrm{O}_{3}$ and $\mathrm{NaNO}_{2}, \mathrm{I} \mathrm{mM}$; carbon sources, $\mathrm{Na}$ acetate, $2 \mathrm{mM}$; malic acid and formic acid, $0.5 \mathrm{mM}$; shikimate, $0.1 \mathrm{mM}$; vitamins, biotin, thiamine, $\mathrm{B}_{12}$, nicotinic acid, $5 \mu \mathrm{M}$; nucleotides, thymine, thymidine, uracil, $0.5 \mathrm{mM}$; amino acids, arginine, aspartate, cysteine, glutamate, isoleucine, leucine, methionine, proline, serine, threonine, valine, I 0 mM; alanine, phenylalanine, $0 \cdot 1 \mathrm{mM}$. Tyrosine at $2 \mathrm{mM}$ was used for development of resistant strains; antibiotics, streptomycin $25 \mu \mathrm{g} / \mu \mathrm{l}$; polymixin-B 100 $\mu \mathrm{g} / \mathrm{ml}$.

Incorporation of $\left[{ }^{14} \mathrm{C}\right]$-labelled materials. $\left[{ }^{2-14} \mathrm{C}\right]$ acetate $(25 \mu \mathrm{Ci}, 55 \mu \mathrm{Ci} / \mathrm{mmol})$ was added to an exponentially growing culture ( $100 \mathrm{ml}$ ) of the acetate requiring mutant $\mathrm{I} I 63$ growing in acetate supplemented medium and samples $(5 \mathrm{ml})$ were removed at intervals up to $8 \mathrm{~h}$. Organisms were immediately collected on a membrane filter and washed $(8 \times)$ with small volumes of medium. After drying, the filters were glued to an aluminium planchette and isotope incorporation estimated in a Nuclear Chicago low background gas-flow counter at an efficiency of $30 \%$ and to an accuracy of $\pm 3 \%$. The same procedure was used for measurement of [methyl-14]methionine incorporation into nitrate-reductase deficient, methionine-requiring mutant 2112.

Optimal conditions for mutagenesis. Optimal exposure times to ultraviolet light (u.v.) and $N$-methyl- $N^{\prime}$-nitro- $N$-nitrosoguanidine (NTG) were found by exposing two mutants, I I I I (deficient in nitrate reductase) and I I2I (deficient in sulphate reduction), to the mutagens and observing the dose which gave maximum reversion to wild-type.

Ultraviolet light. Cultures of the mutants were concentrated to $3 \times 10^{9} \mathrm{cells} / \mathrm{ml}$ by centrifugation and resuspended in fresh growth medium. The suspensions were irradiated at $254 \mathrm{~nm}$ under a Camag Universal u.v. lamp (Camlab, Cambridge). Samples (I ml) were removed at intervals and plated directly on minimal medium to score revertants, and also diluted and plated on supplemented medium to estimate viable count.

Nitrosoguanidine. A $4 \mathrm{ml}$ suspension containing $3 \times 10^{9}$ cells $/ \mathrm{ml}$ was added to $\mathrm{I} 6 \mathrm{ml}$ growth medium containing NTG (Aldrich Chemical Co. Inc., Milwaukee, Wisconsin, U.S.A.) to a final concentration of $25 \mu \mathrm{g} / \mathrm{ml}$ at $\mathrm{pH} 8 \cdot 0$. Samples ( $\mathrm{I} \mathrm{ml}$ ) were removed at intervals, filtered through a sterile Millipore filter, washed, resuspended in sterile-distilled water, and plated as described above.

Optimal conditions for penicillin enrichment. The penicillin enrichment technique was applied to the isolation of mutants of Anacystis nidulans. A mixture of wild-type and strain IIII or wild-type and strain II2I cells in the ratio wild-type: mutant (3:I) was grown from $5 \times 10^{7}$ to $6 \times 10^{8}$ cells $/ \mathrm{ml}$ in medium containing $\mathrm{NH}_{4} \mathrm{Cl}$ or $\mathrm{Na}_{2} \mathrm{~S}_{2} \mathrm{O}_{3}$ respectively. The culture was centrifuged, washed and resuspended in minimal medium at $\mathrm{I} \times 10^{7} \mathrm{cells} / \mathrm{ml}$ and then allowed to grow for $4 \mathrm{~h}$ to permit cessation of growth of mutant cells. Under these conditions wild-type cells divided twice in this period, and the final cell count was $3 \times 10^{7}$ cells $/ \mathrm{ml}$. After $4 \mathrm{~h}$ growth penicillin $(60 \mu \mathrm{g} / \mathrm{ml})$ was added to the culture. Samples (I ml) were removed at intervals, filtered, washed to remove traces of penicillin, resuspended in sterile-distilled water and plated on supplemented medium to score the total viable counts. Colonies were then replica plated on to minimal and supplemented medium to score the numbers of wild-type and mutant cells in the sample.

Isolation of auxotrophic mutants. A $2 \mathrm{ml}$ sample of an exponentially growing culture $\left(5 \times 10^{8}\right.$ cells $\left./ \mathrm{ml}\right)$ was added to $8 \mathrm{ml}$ of growth medium containing NTG at a final concentration of $25 \mu \mathrm{g} / \mathrm{ml}$, and incubated for $60 \mathrm{~min}$. The sample was filtered through a Millipore 
filter, washed, and resuspended in $100 \mathrm{ml}$ of supplemented medium. This culture was grown to $5 \times 10^{8}$ cells $/ \mathrm{ml}$ and a $10 \mathrm{ml}$ sample was filtered, resuspended in minimal medium (I0O $\mathrm{ml}$ ) and exposed to $60 \mu \mathrm{g} / \mathrm{ml}$ penicillin for 2 to $2 \frac{1}{2} \mathrm{~h}$ as described above. Penicillin was removed by filtration and washing with $30 \mathrm{ml}$ water for a $\mathrm{I} 0 \mathrm{ml}$ sample and the cells resuspended in $100 \mathrm{ml}$ supplemented medium and allowed to grow to a density of $3 \times 10^{8}$ to $8 \times 10^{8}$ cells $/ \mathrm{ml}$. The culture was diluted and plated on supplemented agar plates as previously described to give 200 to 350 colonies/plate. The colonies were replica plated on to minimal and supplemented agar using filter paper. Colonies which were identified as mutants were picked off, streaked on to supplemented agar, and their growth requirements identified on agar and in liquid medium. This procedure permitted I0,000 to 20,000 colonies to be screened in each experiment.

Isolation of resistance mutants. Cultures were exposed to NTG as described above, and subsequently grown to approximately $8 \times 10^{8}$ cells $/ \mathrm{ml}$ in the absence of the compound to which resistance was being sought. The culture was then plated directly on to agar containing the compound, and resistant colonies isolated.

Nomenclature of mutants. The proposals of Demerec, Adelberg, Clark \& Hartman (I968) have been followed.

\section{RESULTS}

Penicillin enrichment. Wild-type and mutant (I I I and II I I) cells exhibited differential survival during exposure to penicillin in minimal medium (Fig. I). The viable count of strains IIII and II2I decreased to 60 and $80 \%$ respectively of the initial values after $2 \mathrm{~h}$ exposure to penicillin. The viable count of wild-type cells decreased more rapidly, and after $2 \mathrm{~h}$ exposure only $0.5 \%$ of wild-type cells were viable. The viable count of wild-type cells decreased further to $0.15 \%$ after $3 \mathrm{~h}$ exposure to penicillin; after this time no further reduction in viability was observed.

Thus exposure to penicillin equivalent to one doubling time $(2 \mathrm{~h})$ killed $99.5 \%$ of wildtype cells but only 20 to $40 \%$ of mutant cells. This differential survival represents a Ioo-fold enrichment of mutant cells.

Ultraviolet mutagenesis. The survival of strains I 2 I (Fig. 2) and III I (Fig. 3) to u.v. differed, in that the culture of strain I I I appeared to contain a proportion of u.v.-resistant cells which were not observed in cultures of strain I I 2 I. Maximum reversion frequencies, however, occurred at similar doses in both mutants, i.e. at $3 \%$ survival of I I $2 \mathrm{I}$ and I \% survival of I I I I. The number of mutants increased rapidly with increasing exposure to u.v. up to this point, and then decreased at a rate parallel to the inactivation of the culture. The maximum reversion frequencies were $2.3 \times 1 \mathrm{IO}^{-5}$ for I I $2 \mathrm{I}$ and $\mathrm{I} \cdot 8 \times 1 \mathrm{IO}^{-5}$ for IIII.

NTG mutagenesis. The response of strain II I I to NTG $(25 \mu \mathrm{g} / \mathrm{ml})$ is shown in Fig. 4 : the viable count decreased with increasing exposure. The number of mutants increased rapidly with time, until a maximum was attained after 60 min exposure. At this time, $0.4 \%$ of the population were viable and $3.52 \%$ of these survivors were revertants to wild-type. Of these revertants $3.4 \mathrm{I} \%(0.12 \%$ of the total survivors) had acquired filamentous form (Fil).

Characterization of mutants. The mutants isolated by the methods described above are shown in Table I. Nitrate reductase-deficient mutants were isolated at high frequencies (approximately $\mathrm{I} \times \mathrm{IO}^{-2}$ ) after penicillin treatment, but were found at lower frequency $\left(\mathrm{I} \times \mathrm{IO}^{-4}\right)$ without enrichment. Acetate-requiring mutants were observed with frequencies of $\mathrm{I} \times \mathrm{IO}^{-5}$ in the absence of enrichment and $5 \times \mathrm{IO}^{-3}$ following enrichment. Biotin, phenylalanine and methionine-requiring strains were recovered with frequencies of approximately 


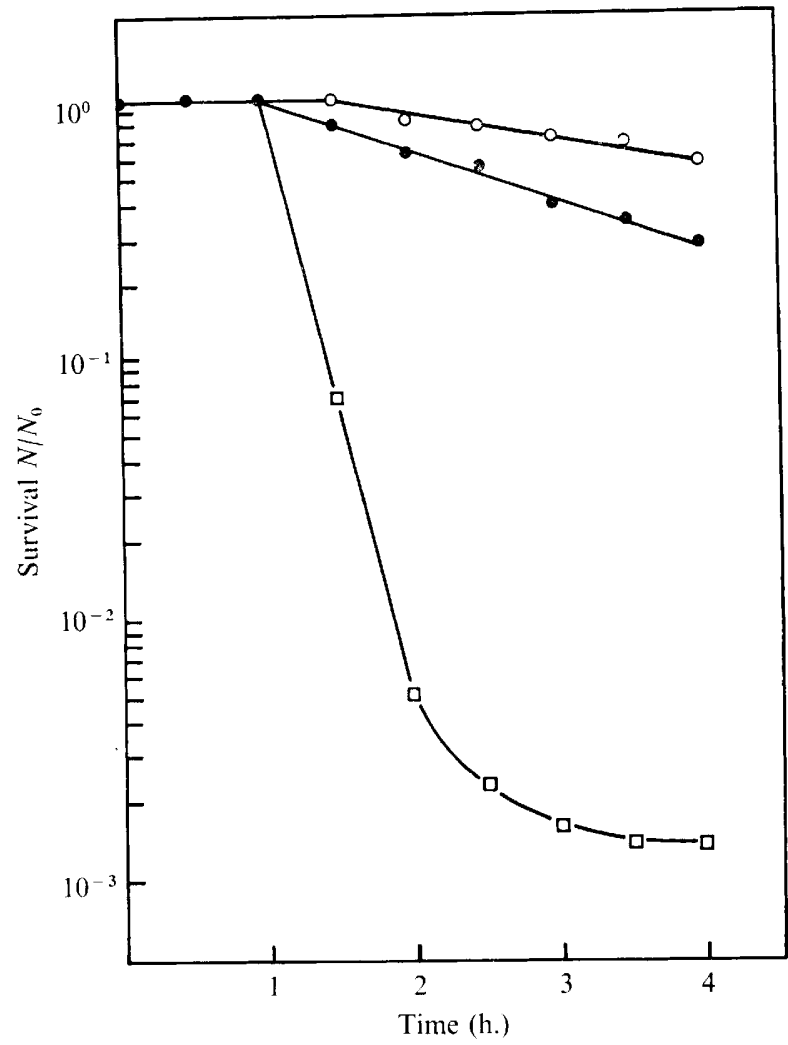

Fig. I. The survival of wild-type Anacystis nidulans ( $\square-\square)$, and mutants I I2 I (O- $\bigcirc)$ and I I I ( ) during exposure to penicillin, $60 \mu \mathrm{g} / \mathrm{ml}$.

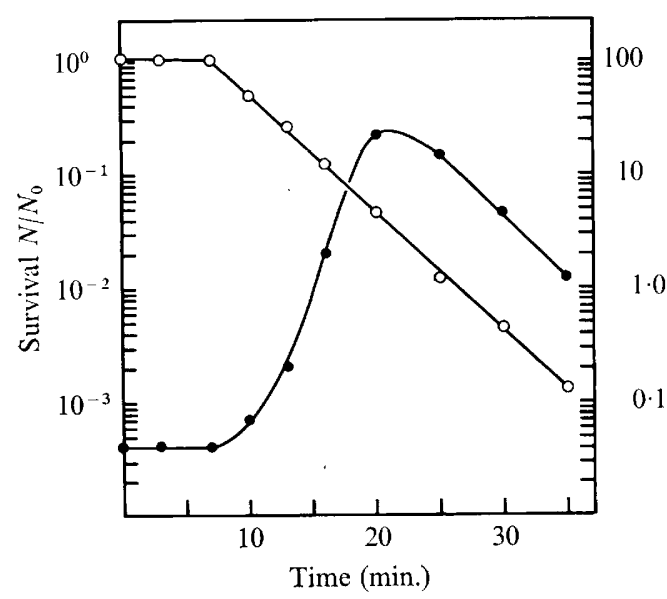

Fig. 2

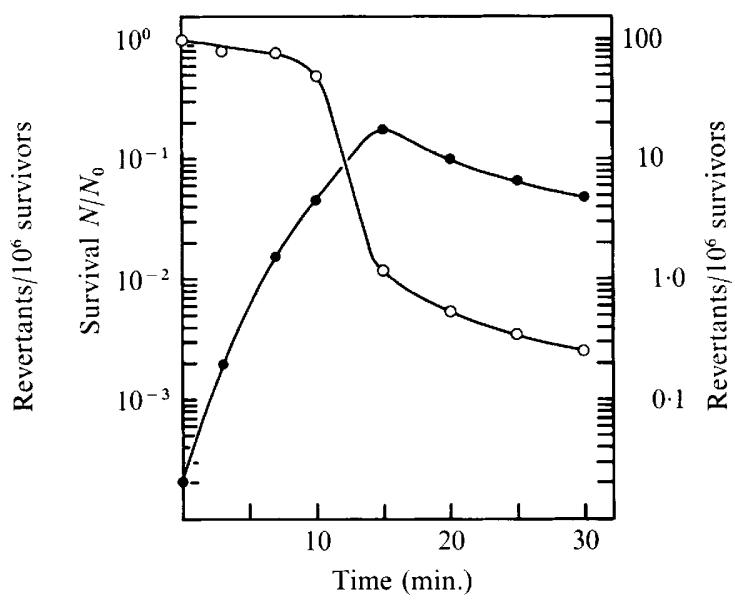

Fig. 3

Fig. 2. Survival of strain I12I $(\mathrm{O}-\mathrm{O})$ and reversion to wild type $(\bullet \bullet)$ during u.v. irradiation.

Fig. 3. Survival of strain I I I I $(\mathrm{O}-\mathrm{O})$ and reversion to wild-type $(\bullet-\bullet)$ during u.v. irradiation. 


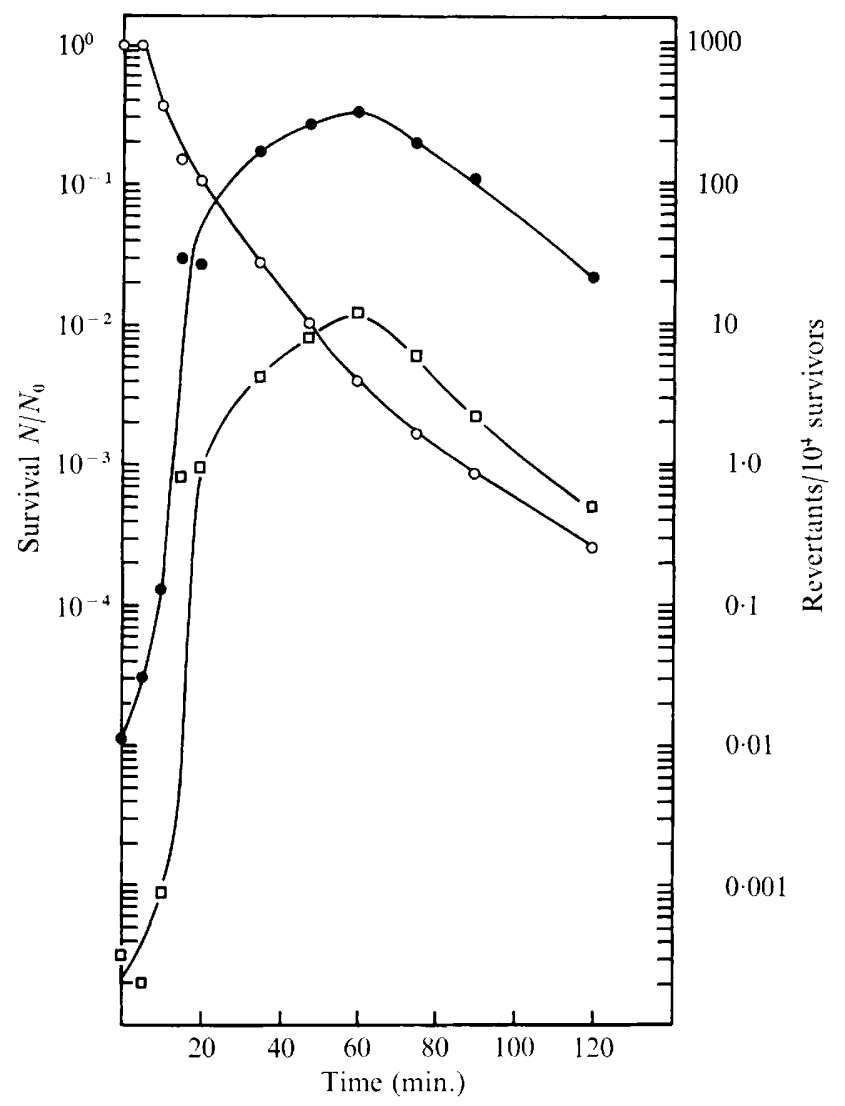

Fig. 4. The survival $\left(\mathrm{O}_{-} \mathrm{O}\right)$ of strain II I I to NTG and mutation to wild-type $\left(\mathrm{Nit}^{+}\right)(\bullet-\bullet)$ and $\mathrm{Nit}^{+}$Fil mutants $(\square-\square)$.

$5 \times \mathrm{IO}^{-4}$ following enrichment, and were not isolated in experiments where enrichment was not applied. NTG-induced mutants resistant to streptomycin, polymixin-B or tyrosine arose at low frequencies in the range $10^{-5}$ to $10^{-7}$. Filamentous mutants were found at high frequencies $\left(\mathrm{IO}^{-2}\right.$ to $\left.\mathrm{IO}^{-3}\right)$ even though penicillin enrichment could not be applied to mutants of this type.

The growth rates of the mutants isolated were similar ( $\pm 10 \%)$ to that observed in wildtype Anacystis nidulans, i.e. 0.1 I doublings/h. As far as they were tested the auxotrophic strains described had a specific growth requirement; for example I 163 (Ace) did not grow on malate, citrate, fumarate, glutamate, glycine, glucose or glyoxylic acid, and the requirement for methionine of strain 2 I I 2 (Nit Met) could not be replaced by $\mathrm{Na}_{2} \mathrm{~S}_{2} \mathrm{O}_{3}$, cysteine, homocysteine, choline, formate, acetate, pyruvate or vitamin $\mathrm{B}_{12}$. For auxotrophic mutants the accumulation of ${ }^{14} \mathrm{C}$-labelled nutrient was followed during growth. Under the conditions employed the acetate requiring strain II63 incorporated $\left[2-{ }^{14} \mathrm{C}\right]$ acetate at a linear rate twice that of the wild-type; after $7 \mathrm{~h}$ growth incorporation ceased. The assimilation of [methyl-14 C]methionine by the methionine requiring strain 2 I 12 was faster than the wildtype, but after $2 \mathrm{~h}$ entry into both cultures continued at a reduced, similar, rate up to a period of at least $8 \mathrm{~h}$. 


\title{
DISCUSSION
}

The results demonstrate that u.v. is a relatively inefficient mutagen for Anacystis nidulans, giving a maximum crude mutation frequency of $2.3 \times 10^{-5}$ for the two genes tested. NTG, however, was 1000-fold more effective in mutagenesis, giving a maximum mutation frequency of $3.4 \times 10^{-2}$ and producing double mutants with a frequency of up to $1 \cdot 2 \times 10^{-3}$. The maximum mutation frequency resulting from exposure to NTG occurred at a dose where $0.4 \%$ of the culture was viable. This is much less than in bacteria, in which maximum mutation frequencies occur at doses which permit $50 \%$ survival of the treated culture (see Adelberg, Mandel \& Chen, I965).

All the mutants reported in this paper were isolated after exposure to NTG at $\mathrm{pH} 8$. Preliminary experiments showed no difference in the mutagenic action of NTG in growth medium ( $\mathrm{pH} 8$ ) or in phosphate buffer at $\mathrm{pH}$ 5. At $\mathrm{pH} \mathrm{8,} \mathrm{diazomethane,} \mathrm{a} \mathrm{decomposition}$

\section{Table I. Mutants isolated in Anacystis nidulans}

\begin{abstract}
Auxotrophic, drug resistance and morphological mutants of Anacystis nidulans isolated following treatment with NTG. All mutants isolated were stable, except the three acetate mutants. Strain I I6I had a very high spontaneous reversion frequency; when colonies were replicated from acetate to minimal medium each colony developed between I-5 revertant sectors. Strains I I 62 and I 63 had less extreme, but still high, reversion frequencies, $\mathrm{I}$ in $10^{4}$ and 2 in $10^{6}$ cells respectively. Mutants requiring the following growth factors were not found, after screening $1 \times 10^{4}$ to $3 \times 10^{4}$ cells for each one: alanine, arginine, aspartate, glutamate, leucine, iso-leucine, proline, serine, shikimate, threonine, valine, thymine, thymidine, uracil, fumarate, malate, thiamine, vitamin $\mathrm{B}_{12}$, nicotinic acid.
\end{abstract}

\begin{tabular}{|c|c|c|c|c|}
\hline Strain & Mutant & Derivation & Growth requirements & Comments \\
\hline I I I I & nit-I & Wild-type & $\mathrm{NH}_{4} \mathrm{Cl}$ or $\mathrm{NaNO}_{2}$ & $\begin{array}{l}\text { Nitrate reductase } \\
\text { deficient }\end{array}$ \\
\hline I I 2 I & cys-I & Wild-type & Cysteine or $\mathrm{Na}_{2} \mathrm{~S}_{2} \mathrm{O}_{3}$ & $\begin{array}{l}\text { Deficient in sulphate } \\
\text { reduction }\end{array}$ \\
\hline I I4I & bio-I & Wild-type & Biotin & - \\
\hline II42 & bio-2 & Wild-type & Biotin & - \\
\hline II6I & ace-I & Wild-type & Acetate & - \\
\hline 1162 & ace-2 & Wild-type & Acetate & - \\
\hline 1163 & ace-3 & Wild-type & Acetate & $\begin{array}{l}\text { Growth in acetate } \\
\text { only }\end{array}$ \\
\hline II5I & phe & Wild-type & Phenylalanine & - \\
\hline $2 I_{12}$ & nit-I met-I & I I I I & $\begin{array}{l}\mathrm{NH}_{4} \mathrm{Cl} \text { or } \mathrm{NaNO}_{2}+ \\
\text { methionine }\end{array}$ & - \\
\hline $2 \mathrm{II} 3$ & nit-I met-2 & I I I I & As 2122 & - \\
\hline 2111 & nit-1 str-I & I I II I & $\mathrm{NH}_{4} \mathrm{Cl}$ or $\mathrm{NaNO}_{2}$ & $\begin{array}{l}\text { Resistant to } \\
\text { streptomycin } \\
25 \mu \mathrm{g} / \mathrm{ml}\end{array}$ \\
\hline $2 \mathrm{I} 2 \mathrm{I}$ & cys-I str- 3 & II 2 I & Cysteine or $\mathrm{Na}_{2} \mathrm{~S}_{2} \mathrm{O}_{3}$ & $\begin{array}{l}\text { Streptomycin } \\
\text { resistant }\end{array}$ \\
\hline $214 \mathrm{I}$ & bio-I str-2 & I I 4 I & Biotin & $\begin{array}{l}\text { Streptomycin } \\
\text { resistant }\end{array}$ \\
\hline 3I4I & bio-I nit-2 str-2 & $2 \mathrm{I} 4 \mathrm{I}$ & $\begin{array}{l}\text { Biotin }+\mathrm{NH}_{4} \mathrm{Cl} \text { or } \\
\mathrm{NaNO}_{2}\end{array}$ & - \\
\hline 3113 & nit-I met-2 pmx & 2113 & $\begin{array}{l}\mathrm{NH}_{4} \mathrm{Cl} \text { or } \mathrm{NaNO}_{2}+ \\
\text { methionine }\end{array}$ & $\begin{array}{l}\text { Resistant to } \\
\text { polymixin-B } \\
\text { I00 } \mu \mathrm{g} / \mathrm{ml}\end{array}$ \\
\hline I I4I & tyr & Wild-type & 一 & Resistant to tyrosine \\
\hline IIOI & fil-I & Wild-type & - & Filamentous, class II \\
\hline I 102 & fil-2 & Wild-type & - & Filamentous, class I \\
\hline 3III & fil-4 nit-I str-I & 2 III & $\mathrm{NH}_{4} \mathrm{Cl}$ or $\mathrm{NaNO}_{2}$ & $\begin{array}{l}\text { Filamentous class I; } \\
\text { streptomycin } \\
\text { resistant }\end{array}$ \\
\hline
\end{tabular}


product of NTG, is thought to be the principle agent involved in mutagenesis (CerdaOlmedo \& Hanawalt, 1968). The penicillin enrichment technique proved valuable in the isolation of auxotrophic mutants, since the frequency of isolation of such mutants was increased by approximately 20 to I00-fold by this technique. Thus Nit and Ace mutant strains were isolated at frequencies of $\mathrm{I} \times \mathrm{IO}^{-2}$ and $5 \times 10^{-3}$ respectively following enrichment of the cultures, but at the lower frequencies of $\mathrm{I} \times 10^{-4}$ and $\mathrm{I} \times 10^{-5}$ respectively in the absence of enrichment. The degree of enrichment illustrated by these values was in general agreement with the results obtained during the development of the technique. The nitrate reductase deficient mutants appear similar to that described by Van Baalen (I965) and the filamentous mutants (Fil) possessed morphological changes similar to those described by Kunisawa \& Cohen-Bazire (1970), in that IIOI was a long single filament (analogous to class II of Kunisawa \& Cohen-Bazire) and IIO2 possessed cells of variable length up to tenfold that of the wild-type (Kunisawa \& Cohen-Bazire, class I).

The relative difficulty in isolation of auxotrophic and other mutant phenotypes of bluegreen algae has been noted by other workers but it is evident that Anacystis nidulans is sensitive to NTG to an extent comparable to other procaryotes. Although some phenotypes (e.g. Nit, Fil) were isolated at relatively high frequencies, others were not found after extensive screening. The reason for the isolation of only a narrow spectrum of mutants of $A$. nidulans is not known, but may be related to the autotrophic metabolism of the organism since the same difficulties are encountered in the isolation of mutants of autotrophic, eucaryotic algae ( $\mathrm{Li}$, Redei \& Gowans, 1967).

The use of the techniques described in this paper has led to the isolation of auxotrophic mutants which have not previously been reported in blue-green algae, namely those requiring cysteine (thiosulphate), biotin, methionine, phenylalanine and acetate, and the tyrosineresistant mutant.

The authors are indebted to Dr B. M. Faulkner for valuable advice and M. H. acknowledges financial support from the Science Research Council.

\section{REFERENCES}

Adelberg, E. A., Mandel, M. \& Chen, G. C. C. (1965). Optimal conditions for mutagenesis by $N$-methyl$N^{\prime}$-nitro- $N$-nitrosoguanidine in Escherichia coli. Biochemical and Biophysical Research Communications 18, 788-795.

Asato, Y. \& Folsome, C. E. (1969). Mutagenesis of Anacystis nidulans by $N$-methyl- $N$ '-nitro- $N$-nitrosoguanidine and u.v. irradiation. Mutation Research 8, 53I-536.

BazIN, M. J. (1968). Sexuality in a blue-green alga: Genetic recombination in Anacystis nidulans. Nature, London 218, 282-283.

Cerda-Olmedo, E. \& Hanawalt, P. C. (I968). Diazomethane as the active agent in nitrosoguanidine mutagenesis and lethality. Molecular and General Genetics ror, 191-202.

Demerec, M., Adelberg, E. A., Clark, A. J. \& Hartman, P. E. (I968). A proposal for a uniform nomenclature in bacterial genetics. Journal of General Microbiology 50, I-I4.

Herdman, M., FAULKNer, B. M. \& CARR, N. G. (1970). Synchronous growth and genome replication in the blue-green alga Anacystis nidulans. Archiv für Mikrobiologie 73, 238-249.

INGRAM, L. O. \& VAN BAALEN, C. (1970). Characteristics of a stable filamentous mutant of a coccoid bluegreen alga. Journal of Bacteriology 102, 784-789.

KraUS, M. P. (I966). Preparation of pure blue-green algae. Nature, London 21r, 310.

Kumar, H. D. (1962). Apparent genetic recombination in a blue-green alga. Nature, London 196, I I 2 I-I 122.

KumAR, H. D. (1963). Effects of radiations on blue-green algae. I. The production and characterisation of a strain of Anacystis nidulans resistant to ultraviolet radiation. Annals of Botany 27, 723-733.

KumAR, H. D. (1965). Effects of certain toxic chemicals and mutagens on the growth of the blue-green alga Anacystis nidulans. Canadian Journal of Botany 43, 1523-1532. 
Kunisawa, R. \& Cohen-Bazire, G. (1970). Mutations of Anacystis nidulans that affect cell division. Archiv für Mikrobiologie 7r, 49-59.

Li, S. I., RedeI, G. P. \& Gowans, C. S. (1967). A phylogenetic comparison of mutation spectra. Molecular and General Genetics Ioo, 77-83.

PADAN, E. \& Shilo, M. (1969). Short-trichome mutants of Plectonema boryanum. Journal of Bacteriology 97 , 975-976.

PikaleK, P. (1967). Attempt to find genetic recombination in Anacystis nidulans. Nature, London 215, $666-667$.

Shestakov, S. V. \& Khyen, N. T. (1970). Evidence for genetic transformation in the blue-green alga Anacystis nidulans. Molecular and General Genetics 107, 372-375.

Singh, R. N. \& Singh, H. N. (1964a). Ultraviolet induced mutants of blue-green algae. I. Anabaena cycadeae. Archiv für Mikrobiologie 48, I09-1 17.

SingH, R. N. \& Singh, H. N. (I964b). Untraviolet induced mutants of blue-green algae. II. Anabaena doliolum. Archiv für Mikrobiologie 48, I18-121.

Singh, R. N., Singh, H. N. \& Sinha, R. (I966). Mutation and recombination in blue-green algae. In The Impact of Mendelism on Agriculture, Biology and Medicine, pp. 405-430. International Symposium of the Indian Society of Genetics and Plant Breeding, New Delhi.

SINGH, R. N. \& Tiwari, D. N. (1969). Induction by ultraviolet irradiation of mutation in the blue-green alga Nostoc linchia. Nature, London 221, 62-64.

SRIVASTAVA, B.S. (1969). Ultraviolet induced mutations to growth factor requirement and penicillin resistance in a blue-green alga. Archiv für Mikrobiologie 66, 234-238.

Stevens, S. E. \& VAN BAalen, C. (1970). Growth characteristics of selected mutants of a coccoid blue-green alga. Archiv für Mikrobiologie 72, I-8.

Van BaAlen, C. (1965). Mutation of the blue-green alga Anacystis nidulans. Science, New York 149, 70. 